Student elective in Papua New Guinea

SIR,-The outraged chorus of protest from $\mathrm{Dr}$ B A P Karunaratne and others in Papua New Guinea (16 October, $p$ 1115) serves only to focus attention on Dr Kurer's few mild criticisms of Madang Hospital and thereby does the hospital a disservice by distracting attention from the rest of an enjoyable and clearly affectionate account of health care in Papua New Guinea. "Methinks the lady doth protest too much.”

C G O’Bryan-Tear

Westminster Hospital,

\section{Impact of maternal serum alpha-fetoprotein screening on antenatal diagnosis}

SIR,-Ms Susan Standing and others (28 August, $p$ 652) criticised my recent paper (31 July, p 365) on the grounds that it failed to indicate: $(a)$ the number of terminations in which no important abnormality was found; (b) the number of neural tube defects not identified by raised maternal serum $\alpha$-fetoprotein estimation; and (c) the morbidity induced by amniocentesis performed for $\alpha$-fetoprotein estimation. The answer to $(a)$ is zero and to $(b)$ is nine against 68 detected, or $12 \%$. These rather impressive figures were deliberately not quoted because I think that we have been lucky and that larger studies are needed for a proper estimate of sensitivity. ${ }^{1}$ I made no attempt to measure (c) since in the absence of a case-controlled study the data would have been meaningless. We have, however, already documented our protocol and experience in reducing fetal wastage rates in maternal serum $\alpha$-fetoprotein screening programmes. $^{23}$

Ms Standing and others repeat their claim 4 that they have shown the serum $\alpha$-fetoprotein test to be insufficiently sensitive and specific. This is not true; as Wald $e t a^{5}$ pointed out, the King's Lynn study was stopped so prematurely that the $95 \%$ confidence interval on the detection of open spina bifida ranged from $1 \%$ to $81 \%$. For a proper study of the sensitivity and specificity of $\alpha$-fetoprotein screening Ms Standing and others should consult the UK Collaborative Study ${ }^{1}$ or one of the large, properly conducted field trials. ${ }^{6}$ For refutation of the tired old comment that $\alpha$-fetoprotein screening does not detect cases of neural tube defect likely to require longterm institutional care they should look at the report on survival of infants with open spina bifida in relation to maternal serum $\alpha$-fetoprotein levels. ${ }^{8}$

Dr D C Hogg's letter (11 September, p 741) raises several points which I have already dealt with. What worries me most is his view that omelettes can be made without breaking eggs. He is concerned that only $10 \%$ of mothers undergoing amniocentesis because of a raised maternal serum $\alpha$-fetoprotein have spina bifida pregnancies. Has he ever thought of the percentage of mothers over the age of 35 who undergo amniocentesis and subsequently turn out to have children with Down's syndrome? The figure is somewhat less than $1 \%$. In all forms of antenatal diagnosis amniocentesis is performed because one does not know the answer, not because one does. Inevitably there will be some miscarriages which can be attributed to amniocentesis itself, though the figure of $2 \%$ found by the Medical Research
Council working group ${ }^{9}$ is not widely accepted in northern America. ${ }^{10}{ }^{11} \mathrm{Dr}$ Hogg states that under half the pregnant women whom he counsels wish to proceed to serum $\alpha$-fetoprotein screening. In view of his lack of enthusiasm for screening this is a remarkable tribute to their tenacity and perspicacity.

D J H Brock

University Department of Human Genetics, Western General Hospital,

${ }^{1}$ UK Collaborative Study on Alphafetoprotein in 1323-32.

1323-32. Scrimgeour JB, Steven J, Barron L,
Wack DJH, Scrim

Brock DJH, Gosden C. Lancet $1979 ;$;ii: 206.
Standing SJ, Brindle MJ, MacDonald AP, Lacey RW. Br Med 于 1981;283:705-7.

Wald N, Cuckle H, Stirrat G, Lorber J. Br Med $\mathcal{F}$ $1981 ; 283: 105$

Ferguson-Smith MA, May HM, Vince JD, et al. Lancet 1978; i $1330-3$.
Wald NJ, Cuckle HS

Wald NJ, Cuckle HS, Boreham J, et al. Br $\mathcal{Y}$ Obstet Gynaecol 1979;86:91-100

Al Alphafetoprotein in Relation to Neural
Defects. Br 7 Obstet Gynaecol 1982;89:3-7.

Defects. Brf Obstet Gynaecol $1982 ; 89: 3-7$.
Report to the Medical Research Council by thei Working Party on Amniocentesis. Br f Obstet Gynaecol 1978; suppl 2:1-41.

Simpson NE, Dallaire EL, Millar JR, et al. Can Med

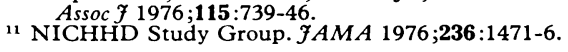

\section{Alcohol update}

SIR,-Dr Richard Smith's Conference Report (2 October, p 959) touches on many important issues. As to the "conflict between the therapists who are 'craftsmen' and those that are "scientists" " surely not only the "craftsmen" but equally the "scientists" have continually to "prove themselves." In alcoholism the clinician has to keep up his research interest and to take notice of research findings, just as the "scientist" should also be a "craftsman" and remain in touch with clinica observations. As Griffith Edwards" rightly puts it: "The worlds of clinical experience and of scientific research ... must be the foundations of any treatment text."

"Therapeutic" techniques that "make some alcoholics worse by ... fostering passivity" cannot be called "treatment."" That group therapy (the central feature of treatment in alcohol units) is “... treatment carried out with and to a larg extent by the patient rather than therapy meted out to him" was stressed in the original description of the first alcohol unit in this country ${ }^{3} 30$ years ago.

The current "controlled drinking" controversy is one example of the need for both "scientists" and "craftsmen" to keep an open mind-as high lighted by Pendery et al' $\mathrm{s}^{4}$ "... new findings and ... re-evaluation of a major affirmative study." Pendery et al's critical reinvestigation of the Sobell' $\mathrm{s}^{5}$ findings is, of course, not "a fatal blow to the controlled drinking movement"; however claims that special behavioural techniques can greatly improve the chances of alcoholics becoming safe controlled drinkers-mainly based on the Sobell's work ${ }^{5}$-again seem open to questioning. Many alcoholics can temporarily keep to a few drinks as long as the "going (psychologically and socially) remains good" "because in most alcoholics the relative "lack of control" does not seem to progress to an absolute "loss of control." This, however, does not mean that loss of control (and with it dependence and the dependence syndrome) is a myth and a "doctor's plot" designed "to keep alcohol problems in [the doctors'] patch." Before problem drinkers reach the loss of control and the dependency phase (and there are degrees of dependency), clearly they could revert to moderate drinking. Once this stage has been reached, however, in clinical practice most alcoholics sooner or later are seen to relapse into uncontrolled drinking once they resume "controlled" drinkingalthough the latter should be possible in "scientific" theory and is temporarily (days or weeks) achieved by many alcoholics and for long periods by a few. The "fashionable idea" that most people drinking long and hard enough will develop "serious drink problems" which "will disappear" when they drink less by no means rules out the possibility that certain people may be more "vulnerable" to alcohol than others and may become dependent much more rapidly and readily. For example, evidence of genetic predisposition has been found by some researchers ${ }^{7}$; and some alcoholics claim that virtually their first alcoholic drink had proved so attractive to them that they wanted to continue drinking. There is no such person as "the" alcoholic, and, as pointed out by Jellinek, ${ }^{8}$ there are likely to be many different (though often overlapping) "alcoholisms."6 Certainly "only a minority" of problem drinkers "would fit the (alcohol dependence) syndrome anyway," a minority, however, who may number well over half a million and increase steadily. ${ }^{6}$

As to the relative importance for prognosis of characteristics of patient, therapist, and their relationship the significance of the patient's characteristics is not a new discovery by "scientists"; it cannot possibly be "resented by craftsmen" to whom it has been well known for many years. ${ }^{3} 9$ The more unstable and unmotivated the patient, however, the greater the possible contribution that could be made by the therapist's interest, experience, enthusiasms, and own motivation $^{6}$ - which may often establish a helpful therapeutic relationship and instil in the patient a motivation which initially is usually lacking in alcoholic patients. ${ }^{36}$

Within the framework of a therapeutic community many an initially unmotivated alcoholic has gradually developed motivation -so that "trying to treat somebody with alcohol problems against his will ..." is by no means "an impossible task." This is an important aspect of the old controversy of compulsory treatment and of the arguments of people's "right to damage themselves and refuse treatment." The alcohol-dependent individual is by no means a completely "free" agent but is more or less affected by his psychological, and/or physical dependence, or both, and need for alcohol. ${ }^{6} \mathrm{He}$ is unlikely to want to damage himself; usually such damage is a highly unwelcome byproduct of his need for alcohol. As to "voluntary" treatment one should remember that most "voluntary" patients are pushed into treatment by wives threatening to leave, bosses threatening the sack, impending court actions for drunken driving, etc.

M M GLAT

University College Hospital Alcoholism Teaching

Centre,

St Pancras Hospital

1 Edwards G. The treatment of drinking problems. London: Grant McIntyre, 1982 .

Glatt MM. Br Med F 1982;285:808.

4endery MI, Maltzman IM, Jolyon West L. Science 1982;217:169-75.

Sobell MC, Sobeli LC. Behav Res Ther 1976;14

195-215. Alcoholism. London: Teach Yourself Books, 1982.

oodwin D. Is alcoholism hereditary? New York: Oxford University Press, 1976.

${ }^{8}$ Jellinek EM. The disease concept of alcoholism. New Glatt MM. Lancet 1959;ii :397-8.

SIR,-There is a certain naivety in Dr Richard Smith's report on the Federation of Alcoholic Rehabilitation Establishments conference, (2 October, p 959). Assessment of alcoholism treatment is not of the nature of assessment of new drugs; rather it is of the assessment of psychotherapeutic techniques with all the inherent difficulties. This cannot be avoided, 